НАУКОВИЙ ВІСНИК

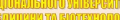

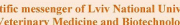

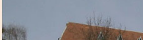
11 thin

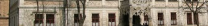
4. Том 21 № 9
Науковий вісник Яьвівського національного університету ветеринарної медицини та біотехнологій імені С.3. Гжицького. Серія: Харчові технології

Scientific Messenger of Lviv National University of Veterinary Medicine and Biotechnologies.

Series: Food Technologies

ISSN 2519-268X print

https://nvlvet.com.ua/index.php/food

\title{
Research of changes in individual physico-chemical parameters of yoghurts using whey protein concentrates
}

\author{
N.B. Slyvka, O.Ya. Bilyk, O.R. Mikhailytska, Yu.R. Hachak \\ Stepan Gzhytskyi National University of Veterinary Medicine and Biotechnologies Lviv, Ukraine
}

Article info

Received 13.02.2019

Received in revised form 13.03.2019

Accepted 14.03.2019

Stepan Gzhytskyi National University of Veterinary Medicine and Biotechnologies Lviv,

Pekarska Str., 50, Lviv,

79010, Ukraine.

Tel $\cdot+38-067-275-37-25$

E-mail:slyvkanat@ukr.net
Slyvka, N.B., Bilyk, O.Ya., Mikhailytska, O.R., \& Hachak, Yu.R. (2019). Research of changes in individual physico-chemical parameters of yoghurts using whey protein concentrates. Scientific Messenger of Lviv National University of Veterinary Medicine and Biotechnologies. Series: Food Technologies, 21(91), 162-166. doi: 10.32718/nvlvet-f9127

The purpose of the work was to investigate the effect of whey proteins and dry whey concentrates on the change of titrated and active acidity during digestion. In order to stabilize the consistency in the production of low-fat yogurts, dry whey was selected that met the requirements of State Standard 4552:2006. It is used to improve the taste of finished products, to add flavor, to improve the texture, as well as to improve overall quality. In addition, dry whey protein concentrate WPC 80 Milkiland was used. The addition of whey protein concentrate does not detract from the organoleptic characteristics of a normalized mixture, which allows it to be used in yogurt technology. The addition of whey proteins has a significant effect on the duration of gel formation. Whey protein concentrate and dry whey reduce the duration of latent fermentation and flocculation stages. The data obtained allows us to predict that they accelerate the coagulation process. This effect is enhanced by increasing the dose of protein concentrates. Conducted coagulation of milk with a different dose and observed changes in titrated and active acidity during the fermentation. Yogurt culture YF-L903, which includes Streptococcus salivarius subsp., Thermophilus, Lactobacillus delbrüeckii subsp. Bulgaricus were used for fermentation. The highest growth rate of titrated acidity is recorded for option 1 ( $0.5 \%$ dry sucrose) and controls that for 4 hours. the fermentation reached $80^{\circ} \mathrm{T}$. The highest rate of decline in active acidity is recorded in option 1 (0.5\% dry sucrose serum). All samples for 4 hours of fermentation reached 4.65-4.72 units. pH. Thus, the acidity slightly increases with increasing the dose of serum protein concentrate and does not increase with the use of dry whey.

Key words: yoghurts, whey protein concentrate, dry whey, titrated acidity, active acidity.

\section{Дослідження змін окремих фізико-хімічних показників йогуртів при використанні концентратів сироваткових білків}

\author{
Н.Б. Сливка, О.Я. Білик, О.Р. Михайлицька, Ю.Р. Гачак
}

Львівський національний університет ветеринарної медицини та біотехнологій імені С.3. Гжицького, м. Львів, Україна

\footnotetext{
Метою роботи було вивчити вплив кониентратів сироваткових білків та сухої сироватки на зміну титрованої та активної кислотності при сквашуванні. Для стабілізаџї консистениії при виробництві низькожсирних йогуртів було обрано суху сироватку, яка відповідала вимогам ДСТУ 4552:2006. Ї̈ використовують для покращення смаку кіниевих продуктів, придання аромату, покращення текстури, а також для покращчення якості в иілому. Також використовували сухий концентрат сироваткових білків WPC 80 Milkiland. Додавання кониентрату сироваткових білків не погіршує органолептичних показників нормалізованої суміші, ио дозволяє використовувати його в технологї йогуртів. Додавання сироваткових білків робить значний вплив на тривалість гелеутворення. Кониентрат сироваткових білків та суха сироватка скорочують тривалість стадій прихованої ферментації та флокуляиії. Отримані дані дозволяють передбачити, щзо вони прискорюють прочес згортання молока. Цей вплив посилюється при збільшення дози білкових кониентратів. Проводили коагуляиію молока з різною дозою і спостерігали за зміною титрованої та активної кислотності під час сквашування. Для заквашування використовували йогуртову культуру ҮF-L903, до складу якої входить Streptococcus salivarius subsp. Thermophilus, Lactobacillus delbrüeckii subsp. Bulgaricus. Найвиший темn наростання титрованоі кислотності зареєстровано для варіанту 1 (0,5\% сухої підсирної сироватки) та контролю, які на 4 год. сквашування досягли $80{ }^{\circ} \mathrm{T}$.
} 
Найвищий темп спадання активної кислотності зареєстровано у варіанті 1 (0,5\% сухої підсирної сироватки). Усі зразки на 4 год сквашування досягнули 4,65-4,72 од. рН. Таким чином кислотність незначно підвищується при збільщенні дози концентрату сироваткових білків і не підвищується при використанні сухої сироватки.

Ключові слова: йогурти, концентрат сироваткових білків, суха сироватка, титрована кислотність, активна кислотність

\section{Вступ}

Одним із основних напрямків державної політики в сфері здорового харчування $\epsilon$ розроблення технології продуктів функціонального призначення (Mazaraky et al., 2012; Gutyj et al., 2017). Ці продукти використовують для профілактики захворювань i зміцнення захисних функцій організму. Використовують їх для зниження дії шкідливих речовин, зокрема для населення екологічно неблагополучних зон.

Серед великої кількості груп функціональних продуктів харчування заслуженою популярністю користуються кисломолочні напої, тобто коров'яче молоко, молоко овець, кіз, кобил та інших тварин, сквашене різними видами молочнокислих бактерій (Hoiko, 2016; Musiy et al., 2017; Bilyk et al., 2017; Nagovska et al., 2018). Традиційними для нашого регіону кисломолочними продуктами є кефір, йогурт, ряжанка тощо (Nagovska et al., 2018).

Йогурт - один 3 найстаріших продуктів, який одержують за допомогою ферментації. Це кисломолочний напій 3 підвищеним вмістом сухих знежирених речовин молока, який виробляється 3 молока або молочної суміші 3 додаванням сухого молока, цукру та інших компонентів, сквашуванням чистими культурами молочнокислих стрептококів та болгарської палички (Nagovska et al., 2018).

Йогурт сприяє кращому засвоєнню мінералів і вітамінів, а також зміцнює імунітет: дослідження показали, що 100-200 г йогурту щодня дозволяють організму активніше виробляти інтерферон; бактерії, що утримуються в ньому, підтримують діяльність лейкоцитів, допомагаючи їм краще захищати організм від інфекцій (Sokolinska et al., 2008). Корисні бактерії, які містяться в йогурті, поліпшують кислотність органів травлення, що допомагає запобігти багатьом проблемам задовго до їх появи. Виходячи з цього, корисні властивості кисломолочного продукту залежать від видового та кількісного складу мікроорганізмів, що містяться у ньому (Slyvka et al., 2018).

Завдання зниження калорійності харчових раціонів, зокрема, завдяки зменшення споживаних жирів, є дуже своєчасним. Особливе значення при цьому набуває пошук ефективних імітаторів жиру штучних або натуральних компонентів їжі, що дозволяють максимально зберегти сенсорні властивості нежирних продуктів. Особливо актуальна заміна молочного жиру, яка обумовлена не лише високою калорійністю жировмісних молочних продуктів, але й дефіцитом молока-сировини. Найбільшого поширення як імітаторів молочного жиру набули рослинні (Gudyma \& Kigel', 2014; Slyvka et al., 2018). Використання їх дозволяє збільшити кількість дефіцитних поліненасичених жирних кислот, поліпшити показник біологічної ефективності. Проте калорійність продуктів на їх основі не змінюється. Відомі технології замінників молочного жиру, що засновані на використанні як основних інгредієнтів вуглеводів (низькомолекулярних крохмалів, декстрину, мальтодекстринів, пектинів), а також синтетичних речовин. Особливу зацікавленість при виробництві кисломолочних напоїв представляють білкові препарати тваринного походження - сироваткові білки. Вони мають високу розчинність, тому під час нагрівання необхідно дотримуватися певної обережності, щоб уникнути денатурації білків, що знижує їх розчинність. Теплова обробка в інтервалі температур $+60 \ldots+140{ }^{\circ} \mathrm{C}$ викликає значну зміну структури та розчинності сироваткових білків, у тому числі і таких термостабільних, як $\alpha$-лактальбумін і $\beta$ лактоглобулін.

Йогурти низькожирні із додаванням в рецептуру сироваткових білків - прекрасний вибір для осіб різного віку, які цінують своє здоров'я і прагнуть зберегти та укріпити його. Вживання йогуртів, що містять у своєму складі сироваткові білки, дозволяє легко і досить швидко, завдяки їх високої засвоюваності, компенсувати дефіцит ессенціальних амінокислот, втамувати почуття голоду і контролювати масу тіла (Nahovska et al., 2017).

Тому при обгрунтуванні інгредієнтів рецептур низькожирних йогуртів та вибору їх кількості враховували не тільки вплив концентратів сироваткових білків на формування структурно-механічні властивості готових продуктів, але і їх оздоровчі властивості.

Відомо, що для отримання нормальної консистенції йогуртів в нормалізованій суміші повинна бути певна кількість сухих речовин і жиру. За літературними джерелами встановлено, що КСБ покращує консистенцію нежирних продуктів.

Метою роботи було вивчити вплив концентратів сироваткових білків та сухої сироватки на зміну титрованої та активної кислотності при сквашуванні.

\section{Матеріал і методи досліджень}

Для стабілізації консистенції при виробництві низькожирних йогуртів було обрано суху сироватку, яка відповідала вимогам ДСТУ 4552:2006. ̈ї використовують для покращення смаку кінцевих продуктів, придання аромату, покращення текстури, а також для покращення якості в цілому. Також використовували сухий концентрат сироваткових білків (КСБ) WPC 80 Milkiland. Це 100\% безпечний продукт від виробництва провідної польської компанії з виробництва молочних продуктів. У 100 г цього продукту міститься 80 г білків, 8 г жирів, 9 г вуглеводів. Енергетична цінність - 376 ккал . Смак: концентрату сироваткових білків нейтральний, молочний, без смакових та ароматичних добавок, що 
дає широкі можливості самостійно змінювати склад і смакові якості напоїв, використовуючи різноманітні натуральні фрукти і ягоди як додаткові інгредієнти.

Концентрат сироваткових білків (зразок 1, 2 і 3) та суху сироватку (зразок 4, 5 і 6) вносили в кількості 0,$5 ; 1,0$ та $1,5 \%$ від маси суміші.

Для заквашування використовували йогуртову культуру YF-L903, до складу якої входить Streptococcus salivarius subsp. Thermophilus, Lactobacillus delbrüeckii subsp. Bulgaricus. Кількість КУО 5 × $10^{12}$. Рекомендована температура інкубації становить $35-45^{\circ} \mathrm{C}$.

Титровану кислотність визначали згідно ГОСТ 3624-92.

\section{Результати та їх обговорення}

Враховуючи властивості сироваткових білків використання їх в молочній промисловості $\epsilon$ доцільним. Використання препаратів сироваткових білків дозволяє досягти потрібного технологічного ефекту i отримати продукт 3 заданими органолептичними властивостями та функціональною спрямованістю.

У табл. 1 наведено органолептичні показники нормалізованої суміші з м.ч.ж. $1 \%$.

Отже, додавання КСБ не погіршує органолептичних показників нормалізованої суміші, що дозволяє використовувати його в технології йогуртів.

\section{Таблиця 1}

Органолептичні показники нормалізованої суміші при додаванні різної кількості КСБ

\begin{tabular}{|c|c|c|}
\hline \multirow{2}{*}{ Показники } & \multicolumn{2}{|c|}{ Доза КСБ, \% } \\
\hline & 0,5 & 1,0 \\
\hline Смак та запах & Чистий, без сторонніх запахів та прис & $\begin{array}{l}\text { свіжому незбираному молоку } \\
\text { олодкуватий та вершковий смак }\end{array}$ \\
\hline $\begin{array}{l}\text { Консистенція } \\
\text { Колір }\end{array}$ & $\begin{array}{l}\text { Однорідна, без осаду та пластівців } \\
\text { Білий }\end{array}$ & \\
\hline
\end{tabular}

Додавання сироваткових білків робить значний вплив на тривалість гелеутворення. КСБ та суха сироватка скорочують тривалість стадій прихованої ферментації та флокуляції. Отримані дані дозволяють передбачити, що вони прискорюють процес згортання молока. Цей вплив посилюється при збільшення дози білкових концентратів. Для підтвердження нашого припущення проводили коагуляцію молока 3 різною дозою і спостерігали за зміною титрованої та активної кислотності під час сквашування.

На рис. 1. представлено зміни титрованої кислотності молочної основи із сухою підсирною сироваткою під час сквашування. Проби відбирали в динаміці через 1, 2, 3 і 4 години.

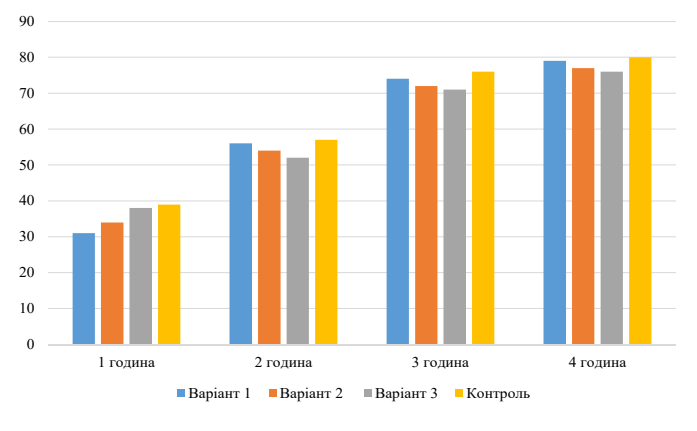

Рис. 1. Зміна титрованої кислотності молочної основи із сухою підсирною сироваткою

Найвищий темп наростання титрованої кислотності зареєстровано для варіанту 1 (0,5\% сухої підсирної сироватки) та контролю, які на 4 год. сквашування досягли $80{ }^{\circ} \mathrm{T}$ у порівнянні 3 іншими дослідними варіантами.
На рис. 2. представлено зміни титрованої кислотності молочної основи із КСБ під час сквашування.

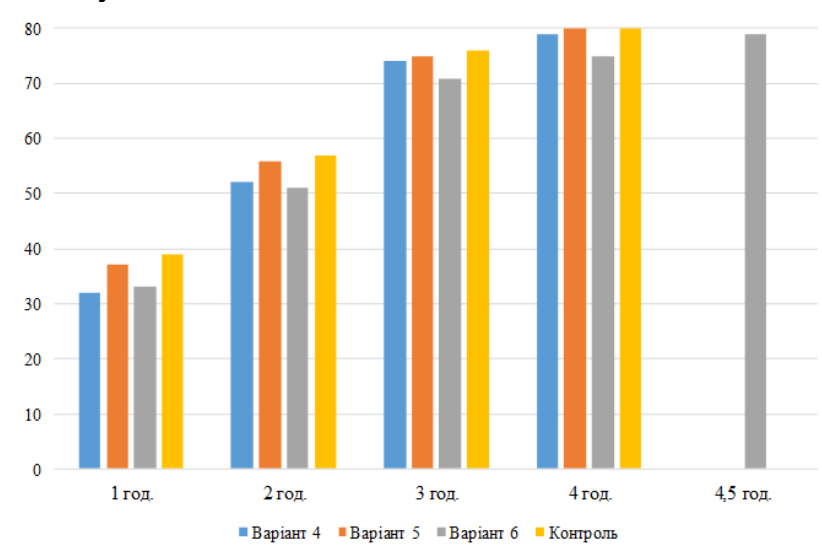

Рис. 2. Зміна титрованої кислотності молочної основи із концентратом сироваткового білка

Найвищий темп наростання титрованої кислотності зареєстровано для контролю та всіх дослідних варіантів крім варіанту 6 (1,5\% концентрату сироваткового білка), які на 4 год. сквашування досягнули $80^{\circ} \mathrm{T}$.

Активну кислотність визначали за допомогою приладу рН-метра. На рис. 3. представлено зміни активної кислотності молочної основи із сухою підсирною сироваткою під час сквашування.

Найвищий темп спадання активної кислотності зареєстровано у варіанті 1 (0,5\% сухої підсирної сироватки ). Усі зразки на 4 год. сквашування досягнули 4,65-4,72 од. $\mathrm{pH}$. 


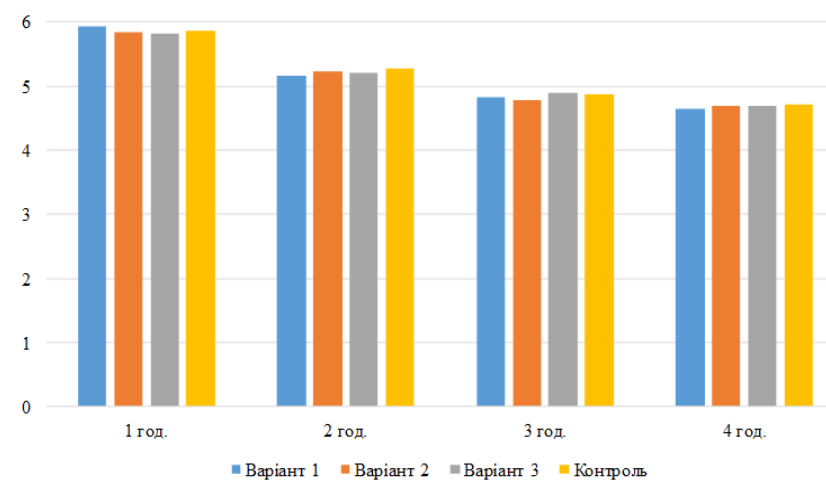

Рис. 3. Зміна активної кислотності молочної основи 3 сухою підсирною сироваткою

На рис. 4. представлено зміни активної кислотності молочної основи із КСБ під час сквашування. У варіанті 6 активна кислотність мала вищий темп спадання у порівнянні із контролем. В кінці сквашування активна кислотність варіанту 6 (1,5\% концентрату сироваткового білка) становила 4,64 од. $\mathrm{pH}$, контролю $-4,72$ од. $\mathrm{pH}$.

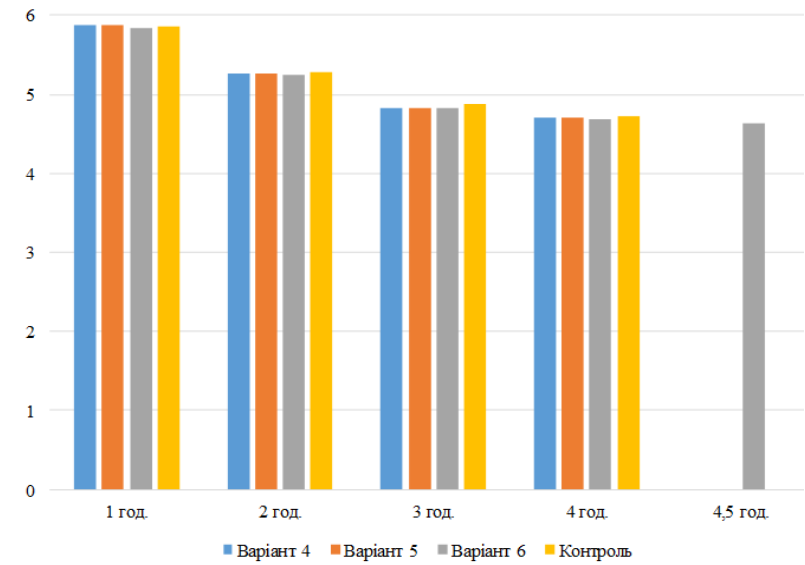

Рис. 4. Зміна активної кислотності молочної основи $з$ концентратом сироваткового білка

3 отриманих результатів видно, що кислотність незначно підвищується при збільшенні дози КСБ і не підвищується при використання сухої сироватки. Це пов'язано з кількістю лактози, яка складає у КСБ 36\%. Крім молочного цукру, препарат КСБ містить велику кількість карбоксильних груп, що збільшує кислотність згустку і готового продукту.

\section{Висновки}

Додавання концентрату сироваткових білків до нормалізованої суміші не погіршує іiі органолептичних показників.

Найвищий темп наростання титрованої кислотності зареєстровано для варіанту 1 (0,5\% сухої підсирної сироватки) та контролю, які на 4 год. сквашування досягли $80{ }^{\circ} \mathrm{T}$. Найвищий темп спадання активної кислотності зареєстровано у варіанті 1 (0,5\% сухої підсирної сироватки). Усі зразки на 4 год сквашування досягнули 4,65-4,72 од. $\mathrm{pH}$.
Таким чином кислотність незначно підвищується при збільшенні дози концентрату сироваткових білків і не підвищується при використанні сухої сироватки.

\section{References}

Bilyk, O.Ya., Dronyk, G.V., Slyvka, N.B., \& Gutyj, B.V. (2017). Calculation of recipes and development of technological production schemes of albumin cheese "Urda" for industry. Scientific Messenger LNUVMBT named after S.Z. Gzhytskyj, 19(75), 65-71. doi:10.15421/nvlvet7513.

Cais-Sokolinska, D. Danków, R., \& Pikul, J. (2008). Physicochemical and sensory characteristics of sheep kefir during storage. Acta Science Polonium, Technol. Aliment, 7, 2, 63-73. https://www.food.actapol.net/ pub/6 2 2008.pdf.

Gudyma, V.V., \& Kigel', N.F. (2014). Vydilennja, identyfikacija ta vyvchennja vlastyvostej molochnokyslyh bakterij iz kefirnyh grybkiv ta kefiru [Selection, identification and study of the properties of lactic acid bacteria from kefir fungi and kefir]. Prodovol'chi resursy. Zbirnyk naukovyh prac'. K., NNC, IAE, 2, 64-70 (in Ukrainian).

Gutyj, B., Hachak, Y., Vavrysevych, J., \& Nagovska, V. (2017). The influence of cryopowder "Garbuz" on the technology of curds of different fat content. EasternEuropean Journal of Enterprise Technologies, $2(10(86)), \quad 20-24 . \quad$ doi: $10.15587 / 1729$ 4061.2017.98194.

Hoiko, I.Yu. (2016). Rozroblennia fitokompozytsii dlia vyrobnytstva funktsionalnykh kyslomolochnykh syriv. Problemy starenija i dolgoletija, 25(2), 273-279. http://nbuv.gov.ua/UJRN/PSD $2016 \quad 25 \quad 2 \quad 12$ (in Ukrainian).

Mazaraky, A.A., Peresichnyi, M.I., \& Kravchenko, M.F. (2012). Tekhnolohiia produktiv funktsionalnoho pryznachennia. K., Kyiv. nats. torh.-ekon. universtet (in Ukrainian).

Musiy, L., Tsisaryk, O., Slyvka, I., Mykhaylytska, O., \& Gutyj, B. (2017). Research into probiotic properties of cultured butter during storing. Eastern-European Journal of Enterprise Technologies, 3, 11(87), 31-36. doi: 10.15587/1729-4061.2017.103539.

Nagovska, V., Hachak, Y., Gutyj, B., Bilyk, O., Slyvka, N. (2018). Influence of wheat bran on quality indicators of a sour milk beverage. Eastern-European Journal of Enterprise Technologies, 4, 11(94), 28-35. doi: 10.15587/1729-4061.2018.140093.

Nagovska, V.O., Hachak, Yu.R., Bilyk, O.Ya., Gutyj, B.V., Slyvka, N.B., \& Mikhailytska, O.R. (2018). Influence of thistle grist on organoleptic, physicochemical and microbiological parameters of kefir. Scientific Messenger of Lviv National University of Veterinary Medicine and Biotechnologies, 20(85), 166170. doi: $10.15421 /$ nvlvet8530.

Nahovska, V., Hachak, Y., Myhaylytska, O., \& Slyvka, N. (2017). Application of wheat brans as a functional ingredient in the technology of kefir. Scientific Messenger of Lviv National University of Veterinary Medicine and Biotechnologies, 19(80), 52-56. doi: 10.15421/nvlvet8011. 
Науковий вісник ЛНУВМБ імені С.3. Гжицького. Серія: Харчові технології, 2019, т 21, № 91

Slyvka, N.B., Myhaylytska, O.R., Nahovska, V.O., \& Bilyk, O.Ya. (2018). The use of pear fillers in kefir technology. Scientific Messenger of Lviv National
University of Veterinary Biotechnologies. 20(90), 10.32718/nvlvet9013.
Medicine and 63-68. doi: 